\title{
Balkanologie
}

Balkanologie Revue d'études pluridisciplinaires

Vol. $15 n^{\circ} 2 \mid 2020$

Pour une approche socio-historique de l'action collective dans les Balkans

\section{Vernacular Entanglements: Islam and Communism in a Bulgarian Village}

Enchevêtrements vernaculaires : islam et communisme dans un village bulgare

\section{Detelina Tocheva}

\section{(2) OpenEdition}

\section{Journals}

Electronic version

URL: http://journals.openedition.org/balkanologie/2627

DOI: $10.4000 /$ balkanologie.2627

ISSN: 1965-0582

\section{Publisher}

Association française d'études sur les Balkans (Afebalk)

Electronic reference

Detelina Tocheva, "Vernacular Entanglements: Islam and Communism in a Bulgarian Village",

Balkanologie [Online], Vol. 15 n² 2 | 2020, Online since 01 December 2020, connection on 23 April 2021.

URL: http://journals.openedition.org/balkanologie/2627 ; DOI: https://doi.org/10.4000/balkanologie. 2627

This text was automatically generated on 23 April 2021.

(c) Tous droits réservés 


\title{
Vernacular Entanglements: Islam and Communism in a Bulgarian Village
}

Enchevêtrements vernaculaires : islam et communisme dans un village bulgare

\author{
Detelina Tocheva
}

1 Belan is a small village located in the southern part of the central Rhodope Mountains of Bulgaria. ${ }^{1}$ In this locality, since the fall of state-socialism in 1989, notions of what Islam is and how it should be practised have been interwoven tightly with notions of communism. ${ }^{2}$ The local Muslims have Bulgarian as their first language and belong to the Sunni Hanafi strand; they are also known as Pomaks. ${ }^{3}$ Most self-identify as Bulgarians, sometimes as Bulgarian Muslims. ${ }^{4}$

2 All actively practising Muslims in Belan are elderly people, with pronounced religiosity being considered unusual and inappropriate for all those who do not belong to the category of the "elderly." The "elderly" (stari) are also called "retired" (pensioneri), a term referring to the fact that they receive an old-age pension. To the present day, some old persons have continued to be identified as "communists" even though the Communist Party, to which they previously belonged, was renamed as Socialist in 1990.

3 In describing some elderly villagers as "communists," their co-villagers do not refer to past Communist Party membership as such. Prior to the regime change in 1989 many were members with no special commitment, and are not called "communist" today. "Communist" means that a person had an active individual involvement in the Party structures before 1989 and a pronounced past and/or current fidelity to the formerly Communist, now Socialist, Party. In addition, a person expressing blunt admiration for the modernizing effects of the state-socialist policies in terms of local material wellbeing, infrastructures and education, is also locally defined as a communist.

In-depth historical studies about the period following the Communist coup on 9 September 1944 have pointed to complex relations between the Communist Party and local Bulgarian Muslim communities. ${ }^{5}$ Since the beginning of my fieldwork in Belan in 
2009, I too have been faced constantly with the continuing importance of local notions of "communism" and "communist" which have played a key role in the ongoing renegotiation of Islamic practice. Even though the proponents of Islam and communism have been a few elderly persons, nearly everyone belonging to this village community has become involved, or taken a position, in the plethora of heated debates around religiosity and communism from the collapse of the regime to the present day. The empirical data presented below show how and why tensions between, and combinations of, commitment to communism and commitment to Islam, are expressed among the elderly, and how they are perceived and negotiated among the village community. The analysis highlights the importance of unproblematic entanglements and open controversies for contemporary social relationships, moral reasoning and community cohesion.

5 This article approaches Islam and communism as vernacular notions. I do not imply that Islam and communism are equivalent categories; neither do I suggest that they are comparable in their theoretical, ideological and scriptural forms, or as lived experience. Starting from empirical evidence, I analyse their locally meaningful interrelatedness. In doing so, I draw, on one side, on authors who investigated experience, practice and the agency-centred dimensions of Islam. Writing about Islam in the Balkans, Henig and Bielenin-Lenczowska define vernacular Islam as "vernacular Islamic cosmologies, religious practice, and moral reasoning and imagination in the lifeworlds of Muslims." ${ }^{\prime 6}$ Their definition overlaps with Elbasani and Tošić's definition of "localized Islam(s)" stressing individual agency and the role of personal interpretations. These authors argue that, while referring to the great Islamic tradition, Muslims act as "purposeful agents" who craft what they consider as correct religious ideas and behaviour. ${ }^{7}$ Building on these approaches, my case study further underscores that the vernacular, localized Muslim identity and practice are inextricably enmeshed in other social identifications and experiences, in particular related to what the people define as "communism."

6 Therefore, on the other side, I take inspiration from Chris Hann's seminal work on postsocialism when I interpret the local vibrancy of "communism" as the continuing importance of the state-socialist past into the present, even though this past is becoming ever more distant, if not mythical. ${ }^{8}$ I add another layer to Hann's analysis by defining the multiple locally meaningful dimensions of communism after 1989 as vernacular communism. The top-down policies of Marxism-Leninism-Maoism varied in time and space, thus creating locally and historically different communist experiments. Human arrangements on the ground, aiming to cope with these policies, were impressively diverse. After the collapse of the regimes, throughout what Caroline Humphrey called "the wide field of postsocialisms," "communism" became a ubiquitous term used for a variety of purposes. ${ }^{9}$ Different actors have purposefully invoked "communism" and "the communists" in order to take a position and respond to contemporary challenges. "Vernacular communism" aims to capture such varying invocations of "communism" as contextually meaningful experiences, practices and commitments.

7 Anthropologists working on Bulgaria brought rich evidence about the vibrancy of vernacular communism. During the three decades following the demise of the regime, the term "communism" has been used widely with a variety of meanings by people from different generations and social backgrounds. Dimitra Kofti analysed one of the 
most widespread usages, that referring to relations of power. In the 2000s, the factory workers among whom Kofti conducted fieldwork where faced with growing precarization. They called "communists" the managers and the owners of the factory, but also those in power before 1989. In the eyes of these blue-collar workers, "communists" were not the proponents of a specific ideology but exploitative elites who kept their dominant position irrespective of the regime change. Conversely, as Kofti also noted, another particularly widespread meaning of "communists" in Bulgaria refers to those considered unable to adapt to the conditions of the neoliberal system. ${ }^{10}$ More generally, "communists" is used in disparaging comments to describe some persons or groups as weak, lacking a sense of individual enterprise and stuck in an obsolete longing for a reliable welfare state. Jana Tsoneva showed how this latter meaning pervaded debates around the 2013 pro- and anti-government protests. Those who viewed themselves as flexible, creative, self-enterprising individuals, destined to become the winners, tended to depict such profiles as retrograde..$^{11}$ In this sense, describing somebody as a communist serves to deny the legitimacy of any public claims she may articulate; her claims are pre-emptively dismissed as a remnant of a disavowed past. As Gerald Creed argued, though longing for some aspects of the communist past can be found in Bulgaria, this form of nostalgia is above all an expression of the ceaseless socioeconomic distress of postsocialism, not a project to restore the past. ${ }^{12} \mathrm{His}$ point holds particularly true for those people from Belan who continue to claim attachment to communism.

8 In close resonance with Gerald Creed's analysis, many of the elderly inhabitants of Belan express a sense of having experienced modernization and progress towards a better future "under communism," meaning most often the last three decades before 1989 , in contrast with the painful socioeconomic decline after this date. This is one of the most popular meanings of Belan's vernacular communism, the only one which is personally endorsed by a few elderly villagers. Other meanings of communism are disparaging; being pointed out as an "old communist" by others is an unambiguous expression of a strong disapproval or even condemnation of some elderly's stubborn conviction that communism had more valuable aspects than what came next, and of the person's arguable inability to live in the present. The continuing vote among the elderly for the Socialist Party, in spite of the obvious absence of any material or symbolic reward granted to the voters by those who get elected, is most commonly interpreted as an evidence of such stubbornness, of a pointless, "retrograde attachment to the past." ${ }^{13}$ Finally, it is particularly disparaging to be called "a communist" when the term is used to point to what is seen as the insincerity of those who were active Communist Party members before 1989 and who suddenly started parading themselves as pious and preachy Muslims right after the fall of the regime. Clearly, those few persons who, right after the regime change, abandoned their strong Party activism overnight and embraced religious fervour are widely described as hypocritical "communists." Oft-unvoiced memories of repression against religion, of aggressive atheist propaganda and the stigmatization of Muslims for their purported backwardness lurk behind people's condemnation of the newfound piety of some "communists," former local Party functionaries who not simply complied with, but personally implemented the regime's merciless policies against other Muslims.

9 The ethnography of the multiple tensions and entanglements between vernacular communism and vernacular Islam found in a small community also aims to allow an understanding of how and why the commitments of those identified as elderly, 
including people who passed away but are remembered for their distinctive engagement and doings, continue to raise empathy, disagreement or resentment. These processes stretch far beyond the group of "the elderly." People's commitments, actual and remembered, contribute to creating a sense of belonging and moral rightfulness among the entire community, including those who live elsewhere and tend to come back rarely to their home village, and those numerous locals who keep some distance from pronounced religiosity. For all these people, these processes help make and remake local notions of Islam. The data used in this article are drawn from my ethnographic fieldwork in the area of Belan, which began in 2009 with a ten-month stay in the village. Since then, I have returned to the area almost every year for shorter visits.

10 After a note about the local background, I describe the two main poles of collective local life in which elderly villagers participate actively: the mosque and the retirement club. I depict combinations and conflicts between engagement with Islam and commitment to communism. Specific life trajectories, marked by major political shifts, but also individual choices largely determine how every one of the elderly people positions her- or himself and how she or he is judged by co-villagers. I conclude that the past and current engagements of the elderly villagers, and the multiple controversies around these engagements, continue to play a role in shaping moral reasoning and a sense of community among the younger generations.

\section{The local background}

11 Belan is a small village of 271 officially registered inhabitants as of 2019, according to data provided by the mayor's office. It is located in the area south from the town of Smolyan, the regional centre. ${ }^{14}$ Belan, like most of the neighbouring villages, is what the local people call "a mixed village." Here, Sunni Hanafi Muslims and Orthodox Christians have lived together for centuries. All locals have Bulgarian as their mother tongue. Muslims have always formed the majority; now they outnumber by far the Christians, who left en masse to larger cities during late state-socialism simply when state policies made both upward social mobility and geographical mobility easier for Christians and more complicated for Muslims. The villagers cultivate a sense of contained expression of religiosity and consider over-pronounced religious practice as inappropriate. This notion is close to what the inhabitants of the Albanian city of Shkodra define as a distinctive "calmness," a contained, "peaceful and participatory attitude" of Christians and Muslims. ${ }^{15}$ Belan is a highly secularized area with low mosque and church attendance, even though the local mosque and church have undergone significant renovation after 1989 thanks to donations, and a minaret was erected in 1993-1994.

The forms of Islam that most villagers consider as normal and authentic have been shaped profoundly by a series of pre-socialist and socialist policies of alternating government-sponsored repression and support, and state-promoted norms of modernity have deeply permeated notions of what are appropriate dress codes, behaviour and ritual life. ${ }^{16}$ Secularizing, pro-Bulgarian state-sponsored movements of the first half of the twentieth century, an outstanding example of which is the Smolyan-based association Rodina (lit. Homeland) particularly active in the region between 1937 and $1944,{ }^{17}$ state-socialist policies of forced secularization and name- 
change campaigns, presented as a necessary step towards modernization, accompanied with intimidation and violence, but sometimes also readily embraced by some Muslims, have left a durable imprint on the local people's views of what it means to be a Muslim. 18

Globalization has become another important feature of contemporary vernacular Islam. Everywhere in the Balkans, the limits between "local" and "imported" Islam are blurred. ${ }^{19}$ As Laura Olson argued, among Bulgarian Muslims, views of what is Islam and how it ought to be practised tend to be shaped by direct or diffuse reactions to widespread Islamophobia and national policies promoting Orthodox Christianity as the marker of true Bulgarianness. Participation in work migration, Internet exposure and the influence of Muslim networks from abroad that advocate newfound religiosities also have an effect, as does a general "interplay between local and translocal discourse and practices." ${ }^{20}$ Belan's inhabitants are no exception. It is nonetheless important to acknowledge that the local people themselves distinguish some practices not as "Muslim" in a universal way, but as "usual," "ours," "traditional," or "our ways" - and they do so irrespective of whether they approve of such practices or question their correctness. ${ }^{21}$ Moreover, over the past three decades of religious liberalization, in Belan, claims to the (in)correctness of "usual" and "new" forms of Islam have referred regularly to vernacular notions of communism.

Islam continues to be an important marker of identity, even though most people do not show external signs of religious belonging. It continues to play a role for the contemporary construction of individual and collective identities, and for the maintenance of kin and local social bonds. This local situation differs from other parts of the Rhodopes, where progressive assimilation of the younger generations to Orthodox Christianity is replacing Islamic practice..$^{22}$ Yet in other areas, local Islamic practice has been reinvigorated among the Bulgarian Muslims thanks to trans-border exchange with Greece and Turkey. ${ }^{23}$ Finally, commitment to globalized forms of pious Salafism and Saudi-styled norms of observance and outlook have become very noticeable in other localities, such as the neighbouring towns of Madam and Rudozem, yet, although widely reported about in the media, they have not proven powerful enough to undermine local, "usual" forms of religiosity. ${ }^{24}$ The people of Muslim origin in Belan typically see themselves as different from their neighbours in Madan and Rudozem. They argue that in these two localities Islam is followed more strictly. This comparison has a twofold meaning: some villagers express regret about their own ignorance of correct religiosity, while others distance themselves from their neighbours from these two towns by considering them as more "backward." The idea of backwardness refers most usually to women's dress, such as a long robe (manta), a veil, whether colourful or darker introduced more recently, and overall intensive religious practice. ${ }^{25}$ In Belan, the Islamic elements in domestic and local rituals are often downplayed and unpublicized. Islamic elements are spoken about as something which is done as a custom and to please the elderly who are used to this way of celebrating. In spite of this claimed weak religiousness, Islam has remained an underlying symbolic component in the contemporary process of making social bonds and moral worlds. Notably, the elderly villagers play a key role in this process. Indeed, in Belan and in the surrounding area, religious practice is usually considered to be related to old age. This applies to local Muslims, as well as to local Orthodox Christians. This means that more active engagement with religion is considered normal 
for those women and men who have reached retirement age. Such engagement is perceived as anomalous for the younger generations, including children and teenagers, and also for those having active work lives and young children, and even generally for those who may have few responsibilities but have not reached retirement age. However, Islamic rituals effectively support an intergenerational relation and, in a reciprocal way, Islamic practice is largely sustained thanks to an intergenerational division of religious labour. Receptions in the houses for childbirth (molitvi, lit. prayers), home-based wedding parties (goste, from gost meaning guest) and commemorations of a deceased family member (pomin, lit. commemoration) require the participation of ritual specialists who are elderly persons and knowledgeable Muslims, able to say prayers and/or read the Qur'an. The intergenerational relationships are ambivalent and in some respects strained. For example, members of the older generation perform rituals and put in place religious-based events for the sake of the entire community, such as the village kurban (a major collective sacrificial meal organized in spring). The younger generations show deference to its organizers; they are expected to attend, and in fact, they never miss kurban or other events like it. ${ }^{26}$ Members of the younger generations also see the participation of elderly ritual specialists in their life-cycle rituals as a guarantee for the validity of these rituals.

The equilibrium of generational roles, however, is under serious threat. The chain of transmission of ritual knowledge and skills is being interrupted. None of the younger men or women has so far shown interest in inheriting the knowledge of the old ritual specialists. Deference and a sense of belonging to the Muslim community do not suffice to insure transmission. The reason for this impending interruption is secularization in the sense of a decline of religious practice and knowledge. Other Islamic authorities, such as the head of the mosque who is affiliated with the district Islamic authority in Smolyan, or unofficial proponents of Saudi-styled Islam (absent from Belan but present in other parts of the Rhodopes), participate in shaping some of the contemporary dynamics of Islam. ${ }^{27}$ They do not, however, take over the usual tasks necessary to put in place domestic and village religious events.

17 Even with the diminishing transmission of ritual knowledge, there is a continuing reassertion of an Islam-based identity among the younger generations. The people of Belan, and especially the younger generations, may seem to outsiders (including other local Muslims) not only deeply secular but also to have a strong Christian bias. The practices that local Islam has in common with Christianity are not perceived by the great majority of local Muslims as syncretic forms of religion. ${ }^{28}$ This is true even with respect to the burial practices which come to the fore in arguments about how to practice Islam. Both local Christians and local Muslims bury the deceased dressed in clothes and placed in a coffin; both place a stone on the grave that carries the deceased's name and photograph. Still, no matter their commonalities, a Muslim is not a Christian and every local inhabitant knows to which religious group she or he belongs.

18 Sweeping out-migration for work is also a major cause for non-transmission of local religious expertise. ${ }^{29}$ In line with the general trends in the Rhodopes since the early 1990s, Belan has undergone a painful combination of economic and demographic decline. Economic depression, however, has not caused a direct decrease in ritual practice. Gerald Creed demonstrated that in the 1990s, ritual life sharply declined in the Bulgarian countryside due to the sudden economic downturn. The villagers among 
whom he conducted fieldwork had simply no more money to organize any festivities, let alone the lavish parties which they held in the $1980 \mathrm{~s} .{ }^{30}$ In Belan, I was told that the domestic rituals had continued to be organized thanks to the produce from domestic agriculture and animal breeding used to feed the guests also in the previous decades. Therefore, religious domestic and village rituals did continue throughout the 1990s and later. The general economic decline, however, has affected the availability of young people, most of whom work at present in the United Kingdom, Spain, Germany, and in larger Bulgarian cities. They tend to come back to their home village only for an annual vacation. The general tendency towards depopulation means that some houses are not in use anymore or are inhabited only during the summer. Hence, a decrease in rituals, such as childbirth celebrations and weddings, derives from depopulation.

The relative prosperity of the village under late socialism, of which old villagers still hold dear memories, came to an end quickly after 1989. The state-enforced dismantlement of the state-run agricultural cooperative and the rapid closing of the couple of small industrial plants undermined the basis of local employment. This closing precipitated the disappearance of symbolically valuable work identities. One could not anymore claim to be, for example, a school teacher. One had to turn into a self-employed shopkeeper with an unclear professional future and an insecure income. Several people tried to establish family businesses; most of these attempts failed. At the moment, the village has a small wood-processing plant that was privatized and underwent significant downsizing, and a shirt-making factory employing approximately thirty women on ridiculously low salaries. Shirt-making factories continue to hire women in this region. But the potential employees are often reluctant to accept the hard working conditions and notably low salaries. The crumbling economy caused out-migration which in turn resulted in diminishing numbers of schoolchildren; therefore, the numbers of classes and teachers dropped too. The mayor's office has gone through constant downsizing since I arrived in 2009, largely because of the cuts made by the central municipal authorities in Smolyan to Belan's budget. There were four full-time employees and a mayor in 2009. By 2019, there was one full-time employee (the mayor) and one half-time employee.

Since 2011, Belan's inhabitants have elected a mayor belonging to GERB, the centralright party which has been the main party of the governing coalition since 2009, and to which the mayor of Smolyan also belongs. This was a major shift after the village's long-term support of the Socialist Party (BSP) at all elections after 1989 for which Belan had gained the reputation of being a "red village." It was, however, a personallymotivated shift rather than an ideological one, by both the new mayor and his constituency. The new mayor had been a well-respected villager, then in his late forties; when he decided to run for the 2011 municipal election in Belan, he joined GERB in the hopes of receiving material support for his village thanks to his new political affiliation with the governing party. But no such support ever came. It is important to mention that no candidate of the Movement for Rights and Freedoms (DPS), usually identified as the Party of the Muslims in Bulgaria, has ever been given a majority of votes in the village during municipal and legislative elections. The voting pattern until 2011 reflected the pro-socialist orientation of the vast majority of the active voters of that time, those who were in their fifties and older.

In variance with the bleak picture of the economy, Belan is a relative success story in one specific sphere. The village has become famous for rural tourism over the past 
twenty years. The picturesque landscapes and the availability of high quality domestic foods - such as milk and meat products, as well as home-grown vegetables, potatoes and beans - have become good marketable assets. In addition, some of the numerous houses that were erected or thoroughly renovated in the 1980s to become home to three-generational families, have now been adapted to offer bed and breakfast. The influx of tourists is mainly seasonal. The tourists are mostly Bulgarians who come for recreation and hiking, but also groups of foreigners travelling in trips organized by agencies for alternative tourism. Although no one lives from tourism alone, income from this activity is a welcome addition to low salaries and revenues from more or less official jobs. Old-age pensions are highly valued because they come in with regularity compared to payments for more or less formal work. When retried people live with the family of their daughter or son, their pension is often used to pay "the bills" (smetkite) for electric, water, TV and the house-phone.

In Belan, the group of "the elderly" is highly variegated. There are several identity subgroups some of which are based on professional identity, while others are not. When I settled in the village in 2009, veterans of the Second World War (frontovatsi), all male, still numbered a few living members. They were identified with a sense of respect as "veterans" by their co-villagers but did not gather in any formal structure. I suspect that their group identity had been celebrated during the state-socialist regime, as it was the case in the rest of the country, and that this long-lasting public recognition has been incorporated into the grassroots symbolic social structure. Former workers from the state-run cooperative farm, former drivers and former teachers form other symbolically important sub-groups among the older villagers. The extreme forms of identifications with "communism" and publicly stated Islamic practice are exemplified by two poles, respectively, the retirement club (pensionerski klub), an association taking cultural and folkloric initiatives, and the mosque. The members of the club do not attend the mosque, and vice versa. This bipolar structure of village sociality means that claims to communism conflict with claims to Islam. Yet some elderly villagers combine these claims smoothly, with the combination of the two being seen as unproblematic by the village community. Besides the members of the club and the mosque attendees, elderly local ritual specialists and villagers of different ages, female and male, partake in pointing to contradictions between Islam and communism, and in defining their acceptable overlapping.

\section{The elderly and the upkeep of ritual life: mosque dynamics and local ritual specialists}

The practising Muslims form a small but symbolically important minority. Although only a handful of old men attend the Friday prayer with some regularity, this weekly gathering is perceived as an important moment on the unwritten weekly time schedule. Similarly, evening gatherings in the mosque during the holy month of Ramazan also attract a small group of worshippers. The majority of non-observant Muslims and Christians show respect during those evenings simply by mentioning that "the elderly" are praying in the mosque.

Here is a vignette to illustrate the kind of respectful attitude that I have encountered. On a summer evening during Ramazan, when the sun had just started to go down, my Muslim host family, some of our friends and I were sitting in front of the house, eating 
fresh salad and small pieces of grilled pork, enjoying the warm air and the beauty of the landscape. My host, a man then in his early sixties, and some of our friends were drinking rakia, the popular Bulgarian brandy. We transgressed three, even four, requirements of Islam: to abstain from eating and drinking during the daylight hours of Ramazan; to abstain from pork; and to abstain from alcohol. At some point, we heard the hodzha (imam) make the call to evening prayer. Even though the mosque is not equipped with loudspeakers, it is easy to hear his voice through the village. My host commented with an expression of solemnity: "Can you hear the hodzha singing? We should not be drinking rakia now." Yes, we confirmed, we did hear the hodzha singing. Then we continued chatting, and those Muslims and Christians who were drinking alcohol continued to enjoy their drink. It was enough to acknowledge that everybody understood (at least) the contradiction between drinking alcohol and belonging to Islam. The moment of required forbearance, according to my host, was limited to the moment when the hodzha is singing. Otherwise, to observe the requirements of Islam, it was enough to show that we were aware of our transgression. Thanks to such small arrangements most people at once pay respect to Islam, notably during Ramazan, and circumvent its most basic rules. However, at another occasion, to which I return in greater detail below, the Islamic ban on alcohol and pork was challenged on purpose in public. This openly provocative act raised anger and resentment among the majority of villagers.

If the sustained practice of Islam is related to old age, in reality this means that only a handful of elderly people go to the mosque, pray at home and/or have some deeper knowledge of Islam. These expressions of faith do not necessarily overlap; one person can go to the mosque but not pray at home, or one may pray but be unable to read the Qur'an. When I began fieldwork in 2009, around twenty old men used to gather in the mosque for the Friday prayer. Most of the non-official local ritual specialists were part of the group. In summer 2018, this group had shrunk significantly, with only nine regular male attendees. In Belan, two categories of Islamic specialists are called hodzhi (sing. hodzha). The first are official representatives of organized Islam officiating in the mosque. They are placed under the authority of the district mufti in Smolyan. The second category includes the local traditional ritual specialists. I use "traditional" for the ritual specialists who have no formal training, are not affiliated with any official authority and do not advocate new, for instance Saudi-styled, forms of Islam - but this is not to imply that tradition is an unchanged entity, untouched by overall political and cultural transformations; quite to the contrary. The tremendous upheavals of the twentieth century have profoundly shaped those Islamic practices and views which have become part of the local norm. The traditional, non-official hodzhi are said to be "ours," or "old hodzhi," while the ritual specialist from the mosque is called "the hodzha of the mosque." There is no competition between these two authorities, since there is a clear division of religious labour between them. Moreover, most of those considered as knowledgeable local Muslims and/or hodzhi have tended to attend regularly the Friday prayer from the 1990s onwards, irrespective of who is the mosque hodzha. The reputation of the different mosque hodzhi has been at the heart of conflicts, but the legitimacy of the office itself is commonly recognized.

In addition, a small group of elderly female mosque-goers had formed a few years prior to my arrival. They used to attend the mosque together during the holy month of Ramazan. In September 2009, at the end of Ramazan, I asked a friendly elderly lady, who was also my neighbour, if I could join her at the mosque. I was concerned about 
the reaction of the hodzha, a young man from a neighbouring village who had been appointed shortly before, and whether the other faithful would find my presence as a non-Muslim inappropriate. My neighbour rejected all my concerns with a wonderful smile and brought me to the mosque that same evening. Other women joined us on the way. None of them seemed to find my presence problematic: "If you want to come it is natural that we let you in," I was told. Or: "Don't worry, the hodzha won't object. And even if he asks something we will tell him that you are with us, that we invited you." On that evening, there were ten men and six women, all of them elderly villagers. When the men and the hodzha saw me entering the mosque, they greeted me and no one asked why I was there. My trousers and my uncovered head did not attract the slightest inspective gaze, not to speak of disapproval. I was dressed in the casual style of most women of my age in the region. All people in Belan knew me personally or indirectly and they knew that I was not of Muslim origin. Before the prayer, the women and men exchanged gifts of cookies, sweets and boxes of fire matches. I was offered gifts too. Being unaware of this practice, I was not prepared to offer a return gift. A few months before my arrival in Belan, the hodzha had imposed to separate the space of the men from that of the women with a curtain. He had argued that it was not "decent" (prilichno) to let men and women pray together. Indeed, upon our arrival and the exchange of gifts, he pulled a large red curtain dividing the room in two parts: the women in the bottom, the men and the hodzha in the front. Standing on the women's side, we were perfectly able to hear the hodzha speaking but could not see the men (nor they us). During the prayer, I was invited to stay with the women and simply follow what was going on.

My neighbour had started going to the mosque and, in her own words, learning how to pray (klaniam se, lit. to bow) and observing the fast (goveene) around 1999. Before that, she had never gone to the mosque. Another elderly woman among those who came to the mosque that evening told us that she knew Muslim prayers since her childhood. Nonetheless, she had started frequenting the mosque a few years earlier, right after retirement. In fact, none of them, they said, had been to the mosque before 1989, as this was something that "only the elderly did." When I asked the women if they were able to understand what the hodzha was saying, one of them replied: "We cannot understand because he utters the prayers in Turkish." Another one corrected her: "No, this is Arabic." In any case, none of them was able to understand. My neighbour intervened with a clarification which I had already heard before, namely that in this region the people do not have this kind of knowledge. "But in Madan and Rudozem, the women know the prayers, even the young girls while they are still children." There was a note of praise in her voice for those knowledgeable Muslims of the two nearby towns. For these women, another evidence of the locals' weak knowledge was the fact that the worshippers could not confirm that the mosque hodzha himself was able to understand what he said in Arabic. But this did not seem to raise any criticism among the women who attend prayers.

Such an uncritical attitude is by no means shared throughout the village. Generally, the villagers do not hold this hodzha in high esteem. He is very young age (just 19 in 2009), but the greater problem is his questionable knowledge. My hosts and numerous other villagers questioned his linguistic skills in Arabic, and it was said that he had no special religious education. The villagers admitted that he never pretended to be highly versed in religious matters, and in this they granted him a smidge of respect because his personal modesty contrasted with the behaviour of the two previous learned imams. 
Still, since the moment the young hodzha had assumed office, the reputation of his grandmother had also undermined his credibility. His grandmother, an elderly energetic and talkative lady who had an orchard near Belan, was known for her foul language. In more recent years, villagers commented that the young hodzha has attended Islamic courses and gained some self-confidence.

The villagers' attitude of combined criticism and tolerance towards the young man appeared as a sort of privileged treatment in comparison with the hard time accorded to his predecessors. According to narratives commonly told in the village, there was one truly despised hodzha. He had arrived from Rudozem at the end of the 1990s as the first learned hodzha in Belan. He pretended, so I was told, to be bringing along superior knowledge about how to be a Muslim. Local practice was wrong, he said, and claimed that the local people who thought of themselves as Muslims were totally ignorant of their own religion. Most villagers perceived his constant critiques as offending. The elderly faithful continued to frequent the mosque without taking position.

Finally, an open conflict opposed the villagers to the hodzha. In 2007, a widely respected teacher, a woman in her thirties, was diagnosed with cancer and soon passed away. Her mother wanted a good burial for her deceased daughter, meaning that she expected that her daughter's body would be dressed, laid in a coffin and covered with kefin (the Islamic shroud), and that a speech would be given during the burial ceremony at the cemetery. Usually, such a speech is delivered by the mayor. The hodzha found these requirements unacceptable - insisting that they were too elaborate for a Muslim burial which should have preferred the body to be shrouded but not dressed, buried directly in the ground, and with little ceremony - and refused to officiate at the burial. The two elderly village women who usually washed the body of a deceased person and prepared it for burial followed the instructions of the hodzha and refused to dress the teacher's body. The family of the deceased woman was outraged. They turned to the "hodzha in chief," the district mufti in Smolyan, who accepted their requirements, came and officiated at the funeral. The most knowledgeable traditional hodzha also officiated during the burial, side-by-side with the mufti from Smolyan. "We buried her with a speech, as it should be. How can you bury a human being and not pronounce a word!" my hostess, an energetic woman born in 1961, commented two years after the event. In the eyes of the immense majority of villagers, the ceremony was executed "as it should be." Because the mufti from Smolyan and the local traditional hodzha officiated, in the eyes of the majority of villagers, the ritual satisfied the common expectations. The mosque hodzha, after this collective denial of his authority, got offended and left the village.

31 Another hodzha came then, again from Rudozem. Practising and non-practising villagers tend to praise him for his ability to work with children - several teenagers learned to read the Qur'an thanks to him and celebrated this achievement with a hatim ritual - and for his actual good knowledge of Islam. But villagers also say that, exactly like his predecessor, he expressed criticism towards the local forms of religion, arguing that in Belan the people had practised the wrong Islam for generations. He also refused to bury deceased villagers in a dressed state and in a coffin, and did not want to hear about speeches during the burial ceremony. "He used to say that we are not believers here, that we don't know anything. He used to have dinner with us sometimes. We, the people from the village, used to feed him," my hostess recounted. Some villagers reported to me that, in spite of his claims to correct Islam, he used to drink beer and 
play cards. Rapidly, disagreements loomed up around issues of correct burial and mutual accusations of lack of conformity with the Islamic norms of conduct. As a result, this hodzha also left. This is when the young man from the neighbouring village was offered to officiate in the mosque. In spite of his questionable knowledge of Arabic and Islam, the villagers seem to accept him, as he continues to hold his position as I am writing.

Religious authority in Belan is by no means restricted to the mosque hodzha. In fact, traditional ritual specialists, some of whom are also called hodzhi, officiate at virtually all life-cycle religious rituals, and during village and house-based kurbani (sing. kurban). The mosque hodzha does not take part in these celebrations, with the notable exception of the funeral. One can become a traditional ritual specialist when one is chosen by an older traditional hodzha. There may also be an agreement among several of the older hodzhi upon the initiation of a younger one. An old revered hodzha, a man employed for many years at the state-run cooperative farm, refused to initiate a younger follower and his knowledge was lost when he passed away in 1989. His decision did not interrupt the tradition, as there were other ritual specialists able to secure continuity by officiating at the rituals. When I arrived in Belan in 2009, twenty years had passed after his death. In spite of this long period, his decision continued to raise incomprehension and a sense of loss for the entire community. Another widely respected traditional hodzha, whom I had the chance to meet, passed away recently. He also refused to choose a follower and gave no explanation for his decision. In fact, one can also acquire reputation as a knowledgeable and pious Muslim by self-study, as did the last man who is currently identified as a hodzha in Belan. When I asked him in summer 2018 (when he was 75) if he wanted to pass his knowledge on to a younger person, he answered that he would like to do so. But then he added: "To whom can I pass on? No one is interested." He echoed the widespread sense of a crisis in transmission mentioned above.

33 An interruption in the formal transmission of knowledge, from senior hodzhi to junior ones, regardless of who is responsible, may not be total. Local religious specialists and "knowledgeable Muslims" may still emerge from within the community. After all, there is no expectation that one individual should possess the totality of knowledge and skills; different individuals can master specific parts of them. Even now, there is a division of religious labour among the observant elderly. It is just that those granted the grassroots title of hodzhi are considered to be more knowledgeable and pious than the others. For example, once I attended a wedding party in a house (goste) where, before the arrival of the guests, five old persons, four men and one woman, said mevliuti for the young couple..$^{31}$ Two of the men were called hodzhi, but the woman and the other man were known simply for their ability to read the Qur'an. All of them were ritual specialists in their own way.

There are many such skills taken up by the elderly in the community. For several decades, one man has specialized in reading prayers during the kurban ritual slaughter. I will return to his case below. Since the early 1990s, an elderly married couple has specialized in cooking the ritual meal keshkek, made of sacrificial mutton and wheat, prepared at home for religious events and for the village kurban..$^{32}$ The couple is known for their good observance of Islam, even though neither the husband nor the wife go to mosque, but simply pray at home. In sum, various forms of piety and knowledge authorize access to the informal status of religious specialist and ritual expertise is distributed, not concentrated. 


\section{The multiple facets of the "communists"}

As mentioned above, mosque attendance excludes participation in the retirement club. However, there are many possible entanglements of commitment to Islam and commitment to communism, as there are clashes. A dozen of men and women are actively involved in the club, a formal organization established in the 1990s that continues to play a prominent role in the life of the village. Retirement clubs were initially established in 1964 throughout the country. They became a popular form of socializing in the 1980s and have continued to expand in the 1990s. Their members usually define themselves by their collective spirit, the origins of which they see as rooted in the state-socialist system..$^{33}$ Since my arrival in Belan, the most active members have been four married couples of Muslim origin and a few Christian and Muslim women. The club gathers once per week in a large room in the building of the village chitalishte, an institution typical of the Bulgarian villages and towns, designed to host cultural and art activities, where there is usually a library and a theatre hall. The club performs folkloric songs at village events, has established partnerships with fellow clubs from the Smolyan region and from distant parts of the country, and actively participates in folkloric song contests organized by the national network of retirement clubs. Although only the head of the club held a prominent position in the Communist Party and has kept renewing his membership in the Socialist Party after 1989, the club as a group is considered to have a communist orientation.

The behaviour of the club members caused a strong dispute a couple of years ago on the day of the annual village kurban, the most prominent village event since 1992. Villagers reported the story, as I was not present at that moment. As usual, virtually all the inhabitants, with their relatives, work colleagues and guests from neighbouring villages were gathering on the main square to share the sacrificial meal organized by the people of Belan. The event takes place on a Saturday. The Friday before the public part, elderly Muslim men gather in the mosque for a special prayer. Before the slaughter of each sheep, the meat of which is used to cook keshkek, an elderly traditional ritual specialist says an Islamic prayer. During the ritual meal, there is no alcohol. The Islamic elements are not publicized, but they are not hidden on purpose either; they are somewhat downplayed while being known to the local people. There are no competing claims to establish a Christian monopoly over the ritual. One participates as a guest when one is related to Belan by his origin, or as an inhabitant of a neighbouring village, or because one has friends or family in Belan. Everyone is welcome, irrespective of religious belonging. ${ }^{34}$

On the day of kurban, the head of the retirement club decided to organize an alternative festive gathering in the room of the club, on the premises of the chitalishte. The members of the club started sharing a meal of grilled meatballs made from minced pork (kiufteta) and salads. The meal was accompanied with rakia. As there are cooking facilities next to the room used by the club, the club members often treat themselves with a festive lunch or dinner. I was also kindly invited in previous years to share a meal during their meetings. This practice of festive socializing usually raises sympathy among the other villagers. But when somebody reported that on the day of the village kurban, a few meters away from the main square where the sacrificial food was being distributed, the club members were eating pork and drinking alcohol, the kurban 
organizers felt outraged by what they felt was a blatant provocation. The club members were compelled to leave their room and join the village event.

Some of the women who usually take part in the organization of kurban and serve the food told me that the head of the club, "this old communist," had gone too far by crossing the commonly accepted code of conduct on the annual kurban celebration. For the women, "communist" encapsulates unambiguous criticism. The head of the club, however, claims his personal commitment to the Communist/Socialist Party as a positive marker of his individual identity. In one of our first conversations, I had asked him if he was of Christian or Muslim origin, as his name did not allow me to guess. His first and family names are identical to those of a prominent Bulgarian Communist leader. His wife wears a loosely knit scarf under her chin, neither too colourful nor too dark, just as do many elderly Muslim and Christian women in Bulgaria, but her name is a typical Bulgarian Christian one. I was not sure how to guess, and so I asked. I received an unexpected answer: "I am not a Christian and I am not a Muslim. For me there is the Party and nothing else! The Party brought me up because I was an orphan from my early childhood." At that moment, I did not dare to ask him more questions about identity and religious affiliation. His answer boiled down to claiming atheism and refusing to discuss religious identity, and cut the possibility to ask further questions related to this issue. In the following months, I befriended his sister, son, daughter-inlaw and two of his grandchildren. It became clear to me that he was born to a Muslim family. I was not able to understand if he had chosen to take the name of the famous Communist leader during the name-change campaign in 1972, or if this name had been given to him in his childhood. No one ever calls him with his Turkic-Arabic name, contrarily to what happens sometimes for those who have also a Christian-Slavic name.

The head of the club is a controversial figure not only because he explicitly claims atheism and fidelity to the Communist Party, nor because he organized the gathering described above. He has been a controversial figure for a long time. It seems that he was personally on the initiative of the destruction of the minaret in 1975-1976, when he was the village mayor. I was told that he and the village secretary of the Communist Party destroyed the minaret with their own hands. Villagers said that the two had claimed to have received an order from Smolyan, but after 1989, when the archives of this period became accessible, villagers from Belan went to Smolyan to search for the order. They found no trace of such a document, and the village gossip claims that the destruction of the minaret was personally initiated by the village mayor and the Party secretary. The controversy around this issue continues. In 2010, I met the former Party secretary, who lives in Smolyan with his children and rarely visits his home village. In a conversation on a different topic, he unexpectedly told me that in 1975 or 1976, he and the mayor had received the order to destroy the minaret. I knew from local narratives that this man also participated actively in the repressions against his Muslim covillagers initiated by the state in the 1970 . I thus avoided asking any question regarding these events, lest he prematurely put an end to discussing the topics I had requested initially. His mention of the order to destroy the minaret was, I guess, a way to tell me his truth, as he must have supposed that other villagers had already told me a different version of the story.

40 In the version he told me, the destruction was justified to some degree by more than an official order. As I had heard from several narratives, after the minaret was destroyed, its foundations were seen to be in the form of a hexagon, which is the usual form of a 
church bell tower. The former Party secretary told me that this meant that an Orthodox church was there before the mosque. Indeed it is possible, as people who condemn the destruction of the minaret also point out, that an earlier church had been transformed into a mosque, as often happened in the Ottoman Balkans. ${ }^{35}$ Thus, so I understood the former secretary to suggest, the destruction had achieved some kind of historical justice.

41 The head of the retirement club, for his part, continues to this day to refuse discussing events related to religious identity with me. He also avoids discussing his involvement in anti-Muslim initiatives of the past. It would seem that he fully pursues an atheist communist identity. But this is not quite so.

Actually, participating in Christian Orthodox rituals is a way for him to reassert his communist identity. Indeed, Christian Orthodox norms provided in some respects a template for state-socialist secularizing policies. ${ }^{36}$ This was also the case of earlier movements, the most famous of which is the locally influential association Rodina. This long-term re-education has left a durable imprint not only on what is considered to be a Muslim, but also on what is considered to be a "communist" approach to Islam and Orthodoxy.

Here is an example. When a respected villager of Christian origin passed away, a service was held in the church. Most villagers of Muslim origin who came to the service stood outside of the church, near the entry. They waited there until the service ended and then went together with those who had been inside the church to go together to the grave. There, everyone witnessed the burial and the speeches made by the mayor and friends of the deceased. In contrast to their reluctance to enter the church, Muslim villagers will enter the house of a deceased Christian and perform mainstream Orthodox ritual acts there, such as lighting a candle. But even lighting a candle for the deceased in a church - the same gesture as what they do in a family house - does not seem appropriate to the immense majority of local Muslims. ${ }^{37}$

The head of the retirement club challenged this local norm too. During that particular funeral, not only did he enter the church but he also stayed inside until the end of the service, a candle in his hand. He stood quite far from the altar and, being an outspoken atheist, also at some distance from the priest. But he was nevertheless inside and held a candle as most Christians did.

The head of the club provides the most radical example of a local sense of incompatibility between communism and Islam. In another case, some local people criticized those few former communists who had engaged with Islam right after the fall of the regime. "When democracy came, all the communists went to the mosque," my hostess explained, expressing criticism for what she found was pure hypocrisy. A wellknown example was provided by a villager who was an active Party member until 1989 and who started to strongly advocate new Islamic norms after the regime shift. When I first met him in 2009, he told me that Islam is the most demanding religion because it appeared after Judaism, which was particularly indulgent, and after Christianity which was stricter than Judaism but less so than Islam. Islam was, according to him, the most demanding religion because it was the most elaborate. The immense majority of the villagers were unfamiliar with the new norms professed by this former Party functionary, which they found unacceptable and offending. Among these new norms, the most shocking requirement seemed to be again burying a deceased person without a coffin and without a speech. Moreover, as the previous involvement of this man with 
the Communist Party was widely known, his ideological about-face raised reactions ranging from mockery to hostility. Villagers assessed his advocacy for new Islamic rules through the lens of his recently abandoned affiliation with communism. This man passed away a few years ago well into his eighties, but his preachy attitude continues to be remembered overwhelmingly with a sense of resentment.

Yet, a combination of (former) commitment to communism and Islamic practice does not necessarily lead to conflict. The members of the retirement club do not avoid all Islamic rituals; for instance, in their houses, many slaughter sheep on the occasion of Kurban Bayram. They also participate in Islamic rituals as a group, as I was able to witness. Once I was attending a home reception organized as a commemoration (pomin) of a man on the fifty-second day after his death. This kind of gathering is preceded by prayers said by the local traditional hodzhi. A sacrificial animal is killed and cooked and a meal is offered to kin, neighbours, friends and work colleagues who pay a visit to the family of the deceased. Usually, people from the same family arrive as a small group; sometimes a group is formed by several persons living in the same neighbourhood. Some groups leave, others arrive; the trickle can continue until the end of the afternoon. During that particular reception, the guests arrived in small groups as usual, talked to the widowed hostess and then were served food. When our group was preparing to leave, around ten of the members of the retirement club arrived, including the head of the club. One of the villagers present in the house announced their arrival: "The retirement club is coming." The members of the club came as a group and observed the usual rules of conduct for such occasions. This situation seemed perfectly normal to those present; it did not elicit any comment or expression of surprise, let alone criticism. Exactly like everybody, the retirement club (and its leader) took part in the collective commemoration, talked to the widow and ate from the ceremonial keshkek.

47 Nor is Islamic piety necessarily perceived as antithetic to sympathy for things associated with the communist regime. Ironically, the villagers used to call by the nickname Lenin one of the religiously knowledgeable men (he has since passed away at the age of ninety). He was given this nickname simply because his family name was similar to that of the famous Bolshevik leader. I had numerous conversations with the local Lenin in the coffee shop where he was used to drop by for a coffee and chat after the Friday prayer. He used to attend the mosque with great regularity. This gentle old man was by no means identified as a "strong communist." He, however, like the immense majority of the elderly, irrespective of their political orientation, expressed nostalgia for the period of great prosperity, as the 1980s are remembered in the area. "Lenin" was proud too, like the rest of Belan, of a villager (his neighbour) who made a career as a deputy in the National Assembly in the 1960s. The deputy was of Muslim origin and had done much to improve the infrastructure in his village. Thanks to him, electricity first arrived in Lenin's house, as the latter told me proudly, and soon after in all the other houses. ${ }^{38}$ The deputy was still praised for his energy and efficacy, as "resourceful" (opraven), and for his active support to the betterment of local living conditions.

The case of another man (born in 1933) provides a similar example of an unproblematic entwining of Islamic practice with sympathy for the Communist/Socialist Party. He is the one who utters prayers at the different kurban slaughters. He showed me his notes of Arabic diva prayers written with Cyrillic letters, the only alphabet that he is able to 
use. He told me that he did not understand what it meant. He knows that these are sacred texts; this is enough for him and for all the villagers who have recourse to him as a ritual specialist of kurban slaughter. He told me that when he was a young man, by 1965 , he worked in the state-run cooperative farm. He then started to specialize in animal slaughter. The old hodzhi decided to initiate him to the prayers to be uttered during a ritual animal killing. From them he received the pieces of paper written in Cyrillic letters that he has been using ever since.

This man is not a mosque-goer; neither does he belong to the retirement club. He has reputation for always voting for the Socialist Party. He is one of those elderly persons whom younger villagers call "strong communists" (silni komunisti). In 2011, a small group of villagers campaigned against the Socialist mayor who was preparing to run for a fourth term. Speaking of this ritual specialist, they told me that they found it useless to try to persuade this "strong communist" to change his mind and give his vote to a non-socialist candidate. But this man had a good reason for that, as he told me. On the one hand, he had suffered from the regime, in particular from the harsh measures adopted by the socialist state against the villages located close to the border with Greece in 1948-1949. ${ }^{39}$ Many families, including his, were displaced to another region and were later allowed to return. This traumatic experience was followed by forced collectivization, a violent name-change campaign in 1972 and strong state control aiming to eradicate religious practice in the subsequent years. This is when the grave stone placed on his father's grave was removed and disappeared, even though the father's name was written in Bulgarian, according to the state-enforced standard, as this man told me. Yet, on the other hand, he underscored that local arrangements allowed religious practice to continue throughout the period of state-socialism: "We have always slaughtered animals for Bayram. Even the Party activists." The sacrificial animals were killed in the barn and their skin buried in the earth. The mayor would always tell him in advance when state controllers were about to come: "The mayor used to tell me: 'I am telling you [that controllers are coming], but do what you have to do."' We were primitive before the collective farm, he told me: "The people used to plough with oxen." Despite the hardships it brought, the socialist state - as he saw it - had brought prosperity to all.

The material progress achieved for everyone is a main argument brought forward by other "strong communists" of this man's generation who are not ready to give up voting for Socialist candidates. This form of commitment to communism by no means encapsulates a project to restore the past. It expresses a sense that state-socialism brought modernity, but also a sense that the era of material betterment came to an end with the arrival of "democracy." "Would Todor Zhivkov have lasted ten more years, it would have been even better here," a member of the retirement club, a man of Muslim origin, told me once. ${ }^{40}$ His remark was meant less to discuss what the communist leader really did; it rather suggested that, in this village like in other Pomak villages, from the point of view of modernization and overall material improvement, the regime change of 1989 has been largely experienced not as "a journey from 'socialism' to 'capitalism', but rather from socialism to its epilogue," as Lenka Nahodilova aptly phrased it. ${ }^{41}$ This shared sense of painful decline among the elderly makes religious repression of the socialist past appear not only as more bearable, but perhaps even as preferable, and the words of the ritual slaughter specialist cited above can be interpreted in this way. 


\section{Conclusion}

Since the demise of state-socialism, "communism" in its multiple vernacular meanings has been related to stormy quarrels about innovation in Islamic norms, but also entangled with the quiet continuation of usual Islamic practice. An overwhelming majority of people from Belan, including those who have left to other places and abroad and who keep returning home, unanimously hold communism for an outdated ideology on the way to extinction; its specific mixture of modernizing achievements and antireligious repression belongs to the past. In the eyes of most local people, the transmission of the knowledge and skills of the old hodzhi and ritual specialists is following the same trajectory. Ironically, however, over the past three decades, notions of communism and Islam have fuelled the crafting of moral codes integral to the making of social bonds for the entire community. Processes of combining some features of vernacular communism and vernacular Islam, and processes of erection of moral fences between them, have contributed to the collective negotiation of notions of decency, rightfulness and community.

\section{NOTES}

1. I use a pseudonym for the name of the village in order to protect the privacy of my informants.

2. A shorter version of this article was published in Bulgarian: TOCHEVA Detelina, "Isliamat $i$ Komunizmat kato Lokalni Iavlenia: Rolite na Vazrastnite Hora v Edno Rodopsko Selo" [Islam and Communism as Local Phenomena: The Roles of the Elderly People in a Rhodope Village], Balgarska Etnologia / Bulgarian Ethnology, $\mathrm{n}^{\circ}$ 1, 2020, p. 35-55. For the present version, I am grateful to the two anonymous reviewers for their critical remarks and helpful suggestions. of course, all shortcomings are mine.

3. According to the 2011 census, ten percent of the total population identify themselves as Muslims. See 2011 Population Census, online: www.nsi.bg (accessed in August 2020). The vast majority belong to the Sunni Hanafi tradition. The ancestors of the Bulgarian Muslims converted during the Ottoman period. Ottoman domination was established in the late fourteenth century and lasted until the late nineteenth (1912 in the studied region). According to research estimates, Bulgarian Muslims, or Pomaks, those whose native language is Bulgarian, are estimated at 130,000 out of a total population of around 900,000 Muslims. CLAYER Nathalie, BOUGAREL Xavier, Les Musulmans de l'Europe de Sud-Est, Paris, IISMM-Karthala, 2013, p. 18-19. Bulgarian Muslims form an ethnoreligious group distinct from the Turkish-speaking Muslim minority of the country. Slavic-speaking Muslims live in Greece, Northern Macedonia, Albania, Turkey and Kosovo.

4. Although the local people do not identify as Pomak spontaneously, I have heard some jokingly saying that they speak the Pomak language, referring to the Rhodope dialect. The latter is in fact commonly spoken by all locals, Muslims and Christians. In other parts of the Rhodope Mountains and in other localities in Bulgaria, self-identification of Bulgarian Muslims varies as Bulgarians, Bulgarian Muslims, Pomaks or Turks.

5. See, for example, GRUEV Mihail, Mezhdu Petolachkata i Polumesetsa. Balgarite Miusiulmani $i$ Politicheskiiat Rezhim (1944-1959) [Between the Pentacle and the Crescent: The Bulgarian Muslims 
and the Political Regime (1944-1959)], Sofia, Kota, 2003; IVANOva Evgenia, Othvarlenite "Priobshteni" ili Protsesa, Narechen "Vazroditelen" (1912-1989) [The Rejected "Integrated" or the Process Called "Rebirth" (1912-1989)], Sofia, Pavlina Nikiforova, 2002. At present, the great diversity among Bulgarian Muslims regarding their self-identification, relation to Islam, as well as voting patterns, undermines the idea that they identify as a community, let alone a political one. See RAGARU Nadège, CAPELLE-POGĂCEAN Antonela, "Les Voix de l'Appartenance: Interpréter les Votes 'Ethniques' en Bulgarie et en Roumanie," Critique Internationale, ${ }^{\circ}$ 53, 2011, p. 119-144; TROEVA Evgenia, Religia, Pamet, Identichnost: Balgarite Miusiulmani [Religion, Memory, Identity: The Bulgarian Muslims], Sofia, Prof. Marin Drinov, 2011.

6. HENIG David, BIELENIN-LENCZOWSKA Karolina, "Recasting Anthropological Perspectives on Vernacular Islam in Southeast Europe: An Introduction," Anthropological Journal of European Cultures, vol. 22, $\mathrm{n}^{\circ}$ 2, 2013, p. 1-11 (3).

7. ELBASANI Arolda, Tošı́́ Jelena, "Localized Islam(s): Interpreting Agents, Competing Narratives, and Experiences of Faith," Nationalities Papers, vol. 45, $\mathrm{n}^{\circ}$ 4, 2017, p. 499-510.

8. CHRIS Hann (ed.), Postsocialism: Ideas, Ideologies and Practices in Eurasia, London and New York, Routledge, 2002.

9. HUMPHREY Caroline (with HANN Chris and VeRDERY Katherine), "Introduction: Does the Category 'Postsocialist' Still Make Sense?," in Hann, Postsocialism, op. cit., 12-15 (13).

10. коғтI Dimitra, “'Communists' on the Shop Floor: Anticommunism, Crisis, and the Transformation of Labor in Bulgaria," Focaal - Journal of Global and Historical Anthropology, vol. 74, 2016, p. 69-82.

11. TSONEVA Jana, "Quantity vs Quality: Citizens and Anti-Citizens in the Bulgarian Protests of 2013," Socio.hu, vol. 17, $\mathrm{n}^{\circ}$ 5, 2017, online: https://socio.hu/en/civil-societies-and-socialmovements (accessed in August 2020).

12. CREED Gerald W., "Strange Bedfellows: Socialist Nostalgia and Neoliberalism in Bulgaria," in Maria Todorova, Zsuzsa Gille (eds), Post-Communist Nostalgia, New York and Oxford, Berghahn Books, 2010, p. 29-45.

13. ibid., p. 30.

14. The town of Smolyan had 27,092 inhabitants in 2019, online: http://www.nsi.bg/en/content/ 6710/population-towns-and-sex (accessed in August 2020).

15. Tošıć Jelena, “The Loudspeaker of Faith in the 'Calm' City: Islam and Urban Diversity in the Contemporary Balkans," in Arolda Elbasani, Olivier Roy (eds), The Revival of Islam in the Balkans: From Identity to Religiosity, Basingstoke, Palgrave Macmillan, 2015, p. 83-102 (89).

16. GRUeV, Mezhdu Petolachkata i Polumesetsa, op. cit.; IVANOVA, Othvarlenite "Priobshteni," op. cit.; NEUBURGER Mary, The Orient Within: Muslim Minorities and the Negotiation of Nationhood in Modern Bulgaria, Ithaca, Cornell University Press, 2004.

17. GRUEV, Mezhdu Petolachkata i Polumesetsa, op. cit., p. 39-52.

18. Name-change campaigns aiming to replace the Turkic-Arabic names of Muslims with Bulgarian-Christian names took place before and under the Communist regime (1912-1913, 1962-1964, 1971-1974, 1985-1989). Among them, the repressive policies in the 1970s seem to have affected the contemporary local population more strongly. See, for example, EMINov Ali, Turkish and Other Muslim Minorities in Bulgaria, London, Hurst, 1997; GRUEV, Mezhdu Petolachkata i Polumesetsa, op. cit.; GRUEV Mihail, “Ot 'Proletarskia Internatsioanlizam' do 'Edinnata Sotsialisticheska Natsia': Politiki kam Balgarite Miusiulmani," in Mihail Gruev, Aleksei Kalionski (eds), Vazroditelniat Protses: Miusiulmanskite Obshtnosti i Komunisticheskiat Rezhim, Sofia, Ciela, 2008, p. 13-105; IVANOVA Evgenia, Othvarlenite "Priobshteni," op. cit.; KRASTEVA Anna (ed.), Communities and Identities in Bulgaria, Ravenna, Longo Editore, 1999; NEUBURGER, The Orient Within, op. cit. 
19. MESARIČ Andreja, "Disrupting Boundaries between Traditional and Transnational Islam: Pious Women's Engagement with Islamic Authority in Bosnia-Herzegovina," Slavic Review, vol. $79, \mathrm{n}^{\circ} 1$, 2020, p. 7-27.

20. olson Laura G., "Negotiating Meaning through Costume and Social Media in Bulgarian Muslims' Communities of Practice," Nationalities Papers, vol. 45, n 4, 2017, p. 560-580 (561). See also BOURSIN Marie-Laure, "Hatim et Ilahi à Roudozem," ANR CirelanMed, 2015, online: http:// cirelanmed.hypotheses.org/231 (accessed in August 2020).

21. SCHMOLLER Jesko, "The Talking Dead: Everyday Muslim Practice in Russia," Nationalities Papers, 2020, p. 1-16, doi:10.1017/nps.2019.132. Online: https://www.cambridge.org/core/journals/ nationalities-papers/listing?q=schmoller\&_csrf=Uhy9upEq-

XzRyxgj0o1fb2QORqEsptUeFsMk\&searchWithinIds=772CCEA76BB15A4162B635506251546D

(accessed in August 2020).

22. TROEVA, Religia, Pamet, Identichnost, op. cit.

23. BOURSIN, "Hatim et Ilahi à Roudozem," op. cit.

24. GHODSEE Kristen, Muslim Lives in Eastern Europe: Gender, Ethnicity, and the Transformation of Islam in Postsocialist Bulgaria, Princeton, Princeton University Press, 2010.

25. For similar self-assessments in contrast to Madan and Rudozem in other parts of the Rhodopes, see TROEVA, Religia, Pamet, Identichnost, op. cit., p. 53, 82, 116.

26. In the Balkans, kurban is a widespread and adaptable Muslim as well as Orthodox Christian sacrificial ritual, practised at the domestic, neighbourhood, or village level. It is also held at Orthodox patron saint days at the sites of churches and chapels, or during professional celebrations of companies and administrations. See, for example, BLAGoEv Goran, Kurbanat $v$ Traditsiiata na Balgarite Miusiulmani [Kurban in the Tradition of the Bulgarian Muslims], Sofia, Marin Drinov, 2004; GIVRE Olivier, Un Rituel «Balkanique» ou un Rituel dans les Balkans? Approche Anthropologique du Kourban en Bulgarie et en Grèce du Nord, PhD diss., Université Lumière Lyon 2, 2006; HRISTOV Petko, SIKIMIĆ Biljana, Kurban in the Balkans, Belgrade, Institut des Études Balkaniques, 2007.

27. oLSON Laura J., "The Multiple Voices of Bulgaria's Unofficial Islamic Leaders," in Arolda Elbasani, Olivier Roy (eds), The Revival of Islam in the Balkans: from Identity to Religiosity, Basingstoke, Palgrave Macmillan, 2015, p. 122-141.

28. LUBANSKA Magdalena, "Muslim Pilgrims at the Orthodox Christian Monastery in Hadzidimovo: Studies in Religious Anti-Syncretism in the Western Rhodopes, Bulgaria," Anthropological Journal of European Cultures, vol. 22, $n^{\circ}$ 2, 2013, p. 91-110.

29. Work migration is a major phenomenon in Bulgarian society, including among the Bulgarian Muslims. See DENEVA Neda, "Transnational Aging Carers: On Transformation of Kinship and Citizenship in the Context of Migration among Bulgarian Muslims in Spain," Social Politics, vol. 19; $\mathrm{n}^{\circ} 1,2012$, p. 105-128. Only a few villagers worked in Greece prior to the 2008 economic crisis. In spite of the geographical closeness of this country, due to the inexistence of a checkpoint nearby Belan and to Greece's economic hardship after 2008, people from Belan tend to establish migrant networks in the United Kingdom, Spain and Germany. In contrast, the opening of a checkpoint in the town of Zlatograd, in the eastern part of the Smolyan region, not simply facilitated migration to Greece for local Bulgarian Muslims and Christians, but greatly contributed to the local economic betterment. See BENOVSKA-SABKova Milena, NEDIN Iliya, "Border Territories, Border People: The Bulgarian Town of Zlatograd as a Border and a Bridge," Anthropology. Journal for SocioCultural Anthropology, vol. 3, 2016, online: http://anthropology-journal.org/wp/journal/borderterritories-border-people-the-bulgarian-town-of-zlatograd-as-a-border-and-a-bridge-milenabenovska-sabkova-iliya-nedin (accessed in August 2020).

30. CREED Gerald W., "Economic Crisis and Ritual Decline in Eastern Europe," in Hann (ed.), Postsocialism, op. cit., 57-73. 
31. Mevliuti are stories about the birth of the Prophet Mohammed. Some representatives of official and/or newfound Islamic norms question the canonical status of these texts because they were composed in the early Ottoman period, long after Prophet Mohammed's death.

32. In the area of Belan and the neighbouring villages, keshkek is considered as a strictly local ritual dish which, according to the locals, cannot be found elsewhere in the Rhodope Mountains. In fact, the term and the recipe are strongly reminiscent of the Turkish ritual dish keşkek, also made from meat and wheat. It is typical for some parts of Greece and is widespread in Iran, probably the country of origin.

33. EFTIMOVA Ivelina, "Pensionerskite Klubove: Polezna za Ostariavaneto Formalna Forma na Neformalni Otnoshenia" [Retirement Clubs: A Formal Form of Informal Relations Beneficial in Old Age], Balgarska Etnologia / Bulgarian Ethnology, ${ }^{\circ}$ 1, 2020, p. 56-74.

34. TOCHEVA Detelina, "Kurban: Shifting Economy and the Transformations of a Ritual," in Stephen Gudeman, Chris Hann (eds), Economy and Ritual: Six Studies of Postsocialist Transformations, New York, Berghahn Books, 2015, p. 107-136.

35. HASLUCK Fredric W., Christianity and Islam under the Sultans, 2 volumes, Oxford, Clarendon Press, 1929.

36. valtchinova Galia, "Orthodoxie et Communisme dans les Balkans: Réflexions sur le Cas Bulgare," Archives de Sciences Sociales des Religions, $n^{\circ} 119,2002$, p. 79-97.

37. Ritual participation in a church is rare among the Muslims from this area, but many of them donate money for the upkeep of the local churches, as I was told by many informants, both Christian and Muslim.

38. About socialist modernization and scientific-technical progress, see BENOVSKA-SABKOVA Milena, "Sotsializmat kato Modernizatsia (Nabliudenia varhu Balgaria)" [Socialism as Modernization (The Example of Bulgaria)], Balgarska Etnologia / Bulgarian Ethnology, n 4, 2009, p. 5-22.

39. GRUEV, Mezhdu Petolachkata i Polumesetsa, op. cit., p. 84-91.

40. Todor Zhivkov (1911-1998) was the head of the Bulgarian state between 1971 and 1989.

41. NAHODILOVA Lenka, "Rural Decline as the Epilogue to Communist Modernization: The Case of a Socialist 'Model' Village," in Ger Duijzings (ed.), Global Villages: Rural and Urban Transformations in Contemporary Bulgaria, London, Anthem Press, 2014, p. 89-104 (101).

\section{ABSTRACTS}

Throughout the three decades following the demise of state-socialism in Bulgaria, the terms "communism" and "communist" have been used continuously by all kinds of actors to respond to a plethora of contemporary challenges. Based on ethnographic research in a village in the Rhodope Mountains among Bulgarian Muslims, this article examines how various meanings of "communism" and "communist" have been called upon constantly by members of all generations in order to negotiate Islamic practice and codes of conduct, those deemed local and usual, and those considered as imported from the outside.

Au cours des trois décennies qui ont suivi le démantèlement du socialisme d'État en Bulgarie, les termes «communisme » et "communiste» ont continuellement été utilisés par toutes sortes d'acteurs afin des répondre à une pléthore de défis contemporains. Basé sur une recherche ethnographique dans un village des Rhodopes parmi des Bulgares musulmans, cet article examine les manières dont différentes significations de « communisme » et « communiste » ont 
constamment été usitées par des membres de différentes générations pour négocier la pratique islamique et les codes de conduite, ceux vus comme locaux et habituels, comme ceux considérés comme importés de l'extérieur.

INDEX

Geographical index: Bulgarie, Rhodopes

Keywords: Islam, communism, Bulgarian Muslims, Bulgaria

Mots-clés: islam, communisme, Bulgares musulmans, Bulgarie

\section{AUTHOR}

\section{DETELINA TOCHEVA}

Centre National de la Recherche Scientifique, France

Groupe Sociétés, Religions, Laïcités (CNRS-EPHE-PSL Research University Paris)

tocheva.detelina[at]gmail.com 